\title{
Novel insights into the aetiology and pathophysiology of increased airway inflammation during COPD exacerbations Maria Tsoumakidou ${ }^{1,2}$ and Nikolaos M Siafakas*1
}

\author{
Address: ${ }^{1}$ Department of Thoracic Medicine, Medical School, University of Crete, Greece and ${ }^{2}$ Lung Pathology Unit, Department of Gene Therapy, \\ National Heart \& Lung Institute, Imperial College, London, UK \\ Email: Maria Tsoumakidou - tsoumak@yahoo.gr; Nikolaos M Siafakas* - pneumon@med.uoc.gr \\ * Corresponding author
}

Published: 22 May 2006

Respiratory Research 2006, 7:80 doi:10.1 186/1465-9921-7-80

This article is available from: http://respiratory-research.com/content/7///80

(c) 2006 Tsoumakidou and Siafakas; licensee BioMed Central Ltd.

This is an Open Access article distributed under the terms of the Creative Commons Attribution License (http://creativecommons.org/licenses/by/2.0), which permits unrestricted use, distribution, and reproduction in any medium, provided the original work is properly cited.
Received: 07 February 2006

Accepted: 22 May 2006

\begin{abstract}
Airway inflammation increases during acute exacerbations of COPD. Extrinsic factors, such as airway infections, increased air pollution, and intrinsic factors, such as increased oxidative stress and altered immunity may contribute to this increase. The evidence for this and the potential mechanisms by which various aetiological agents increase inflammation during COPD exacerbations is reviewed. The pathophysiologic consequences of increased airway inflammation during COPD exacerbations are also discussed. This review aims to establish a cause and effect relationship between etiological factors of increased airway inflammation and COPD exacerbations based on recently published data. Although it can be speculated that reducing inflammation may prevent and/or treat COPD exacerbations, the existing anti-inflammatory treatments are modestly effective.
\end{abstract}

\section{Background}

Exacerbations are a cardinal feature of the natural history of moderate and severe Chronic Obstructive Pulmonary Disease (COPD)[1]. Patients with frequent exacerbations have significantly lower quality of life and increased morbidity and mortality rates [1-4]. Although the effect of COPD exacerbations on lung function has been questioned in the past, recent evidence suggests that exacerbations accelerate long-term decline in lung function, specifically in smokers [5-7]. The mechanism of this acceleration remains largely unknown.

Treatment decisions for COPD patients are frequently made according to exacerbation rates. In the ATS/ERS guidelines it is stated that patients with frequent exacerbations should be initiated a trial of inhaled steroids [8]. Systemic steroids should be administered during acute COPD exacerbations, both in the inpatient and outpatient setting. These treatment strategies indicate the central role of inflammation in the pathogenesis of exacerbations.

Although evidence for increased inflammation on COPD exacerbations has been reviewed previously, there has been little focus on why inflammation increases and which the consequences of this increase are $[9,10]$. Investigating further these important questions may help establish a cause and effect relationship between inflammation and COPD exacerbations. The primary aim of this review is to summarize emerging explanations for $w h y$ inflammation is increased during COPD exacerbations. For practical purposes an attempt is made to categorize aetiological factors of increased inflammation into extrinsic or intrinsic, as it can be seen in table 1 . A secondary aim is to try to explain how increased inflammation is associated with the pathophysiology of COPD exacerbations. 
Table I: Aetiology of increased airway inflammation during COPD exacerbations

\begin{tabular}{ll}
\hline EXTRINSIC FACTORS & INTRINSIC FACTORS \\
\hline I. Acute airway infections & I. Oxidative stress \\
a. Bacterial & 2. Altered immunity \\
H. Influenzae & Tcl/Tc2 imbalance \\
S. pneumoniae & 3. Increased inflammation on stable state \\
M. Cattarhalis & Bronchiectasis \\
b. Viral & Bacterial Colonization \\
Rhinoviruses & \\
Picornaviruses & \\
RSV & \\
Influenza A, B & \\
Coronaviruses & \\
c. Atypical & \\
C. Pneumonia & \\
2. Air pollution & \\
\hline
\end{tabular}

\section{Aetiology of increased inflammation on exacerbations Extrinsic factors \\ I. Airway infections \\ Ia Bacterial infections}

Bacterial infections are generally considered to be the most common causes of COPD exacerbations. It is estimated that more than $40 \%$ of all exacerbations are of bacterial origin $[9,11,12]$. Accordingly, antibiotics should be administered in inpatients and outpatients with acute COPD exacerbation and changes in sputum characteristics suggestive of bacterial infection[8].

The most common bacteria connected to COPD exacerbations are non-typable $\mathrm{H}$. Influenzae, S. Pneumoniae, and M. Cattarhalis $[9,11,12]$. The same bacteria often colonize the nasal mucosa and pharynx of healthy individuals, but in smokers and in patients with COPD impaired mucocilliary clearance and innate immunity allow these pathogens to colonize the lower airways[13]. COPD exacerbations may be triggered by the acquisition of a new bacterial species or by an increase in the absolute number of the same bacteria that colonize the airways or by the acquisition of a different strain from the same bacterial species [14-16].

Airway bacteria initiate airway inflammation through several interconnecting mechanisms. The surface of bacteria allows the complement system to be activated through the alternative pathway, while specific surface molecules of the bacteria, called Pathogen-Associated Molecular Patterns (PAMPs), bind to pattern recognition receptors on a variety of leukocytes and initiate signalling pathways that lead to the activation of NF- $\kappa \mathrm{B}$ and production of proinflammatory cytokines[17]. Once activated, innate immunity can trigger both cell-mediated and antibodymediated adaptive immune responses. This cascade of events leads to increased blood flow to tissue, increased temperature, redness and swelling which characterize inflammation.

A significant number of studies in stable COPD patients suggest that airway bacterial infections are associated with increased airway inflammation(18-21). Finding a relationship between bacteria and inflammation on stable COPD adds weight to the argument that bacteria may play a causative role in airway inflammation during COPD exacerbations.

Soler et al used protected specimen brush and bronchoalveolar lavage sampling to determine inflammatory cell counts, levels of cytokines concentrations and microbial patterns in stable COPD patients and found that increased neutrophils and tumour necrosis factor-alpha (TNFalpha) levels may be related to bronchial colonization[18]. Increased TNF-alpha, as well as myeloperoxidase (MPO) and interleukin-8 (IL-8) levels have been specifically related with $H$. Influenzae infection, as shown by Bresser et al[19]. However, in that study all mediators were measured in frozen sputum and MPO and IL-8 levels were only retrospectively compared to non-infected patients. In fresh sputum samples from COPD patients R. Stockley and his group demonstrated that MPO, neutrophil elastase (NE) activity, IL-8 and LTB4 levels are positively related to sputum bacterial load[20]. Moreover, the type of organism affected sputum MPO levels and NE activity; MPO levels were relatively increased in the presence of Ps. Aeruginosa compared to H. Influenzae and to M. Catarrhalis. There have been also reports for decreased secretory leukocyte protease inhibitor (SLPI) in sputum samples from COPD patients colonised with bacteria[20,21]. Upper airways inflammation in COPD is also increased when there is bacterial colonization[22]. All these results taken together suggest that bacteria are 
actively involved in the mechanisms of increased inflammation in stable COPD. It would be logical to assume a similar association for COPD exacerbations.

A large prospective longitudinal study by Sethi et al addressed the hypothesis that patients with bacterial-positive exacerbations show increased inflammation compared to bacterial-negative exacerbations[23]. Among $\mathrm{H}$. Influenzae, $\mathrm{H}$. Parainfluenzae and $\mathrm{M}$. Catarrhalis positive exacerbations, $\mathrm{H}$. Influenzae and $\mathrm{M}$. Catarrhalis demonstrated higher sputum TNF-alpha and NE levels compared to bacterial-negative exacerbations. Moreover, increased NE levels above a certain level could distinguish bacterial from non-bacterial exacerbations with $71 \%$ sensitivity and $84 \%$ specificity. Others have failed to report any difference in sputum NE levels and other fluid-phase mediators between patients with $\mathrm{H}$. Influenzae exacerbations or bacterial-negative exacerbations[24]. This discrepancy may be due to differences in sputum induction time or in sputum processing or in the assays used for the detection of fluid-phase mediators. Another intriguing hypothesis is that different strains of the same pathogens may induce different levels of inflammation and subjects taking part in different studies might have been infected by different strains of $\mathrm{H}$. Influenzae. It was recently shown that $\mathrm{H}$. Influenzae strains isolated from COPD patients during exacerbation induce more inflammation than strains of the same pathogen isolated from colonizers[16]. The close association between airway infections and increased inflammation during COPD exacerbations has been further confirmed by a report of increased systemic inflammation in infected patients during exacerbation[25].

Consistent with these observations, airway inflammation can be decreased with treatment of the infection. Early evidence came from a relatively small study, which showed that neutrophilic mediators' levels may decrease after treatment of bacterial exacerbations[26]. Gompertz et al confirmed that there are significant decreases in neutrophilic inflammatory mediators after treatment of purulent exacerbations[27]. Most importantly, White et al studied patients with bacterial exacerbations and demonstrated a significant fall in sputum leukotriene B4 (LTB4) levels and an increase in SLPI levels in patients in whom bacteria were eradicated, but not in those in whom bacteria persisted on stable state[24]. Moreover, MPO and LTB4 levels were significantly lower and SLPI levels significantly higher in patients with treated compared to patients with untreated bacterial infections on stable state.

In conclusion, three major findings support the hypothesis that bacterial infections are actively implicated in the mechanisms of increased airway inflammation during COPD exacerbations: 1) bacterial infections increase airway inflammation in colonized stable COPD patients 2) bacterial-positive exacerbations show increased inflammation (particularly of neutrophilic type) compared to bacterial-negative exacerbations and 3 ) eradication of bacteria after a bacterial exacerbation is accompanied by a significant decrease in airway inflammation. A summary of these findings is presented in table 2.

\section{Ib Viral infections}

Respiratory viruses are important triggers of COPD exacerbations. Initial studies using serology and cell cultures for detecting viral infections suggested that $30 \%$ of COPD exacerbations are related to viral infections [28-30]. Later studies using the more sensitive method of reverse transcriptase polymerase chain reaction showed that $40 \%-$ $50 \%$ of COPD exacerbations may be secondary to viral infection[31,32]. Rhinoviruses, picornaviruses, respiratory syncytial virus, influenza A and B and coronaviruses are more frequently detected[31,32].

Possible mechanisms of viral-induced inflammation have been described. The airway epithelial cell is the principal host cell for most respiratory viruses[33]. Viral replication in the epithelial cell triggers intracellular signalling pathways, including activation of $\mathrm{NF \kappa B}$, which leads to increases in the secretion of multiple cytokines and recruitment of multiple leukocytes to the airways[33]. Antigen presenting cells are of particular importance, because binding of viruses to these cells induces innate and adaptive immune responses and $\mathrm{T}$ lymphocyte activation[34].

There is convincing data that viruses induce inflammation in asthma[35]. In animal models of emphysema, latent adenoviral infection amplifies the emphysematous destruction and increases the inflammatory response[36]. In stable COPD latent adenoviral infection has been associated with severe emphysema and increased inflammation[37]. The group of J Wedzicha showed that viral infections might be implicated in the mechanisms of increased airway and possibly systemic inflammation during COPD exacerbations. Plasma IL-6 and fibrinogen levels were higher during viral than non-viral exacerbations, although the difference just failed to reach statistical significance[31]. However, in that study viruses were detected in nasal samples and it has been shown that in COPD patients respiratory viruses are detected more frequently in induced sputum than in nasal lavage[32,38]. When rhinovirus infection was detected in induced sputum samples a significant correlation was demonstrated between rhinovirus infection and increased sputum IL- 6 levels on COPD exacerbations[38].

Further to these observations, two recent studies showed that viral airway infections during COPD exacerbations are related to airway eosinophilia[39,40]. This new find- 
Table 2: Studies showing an association between bacterial infections and airway inflammation in stable COPD and on exacerbations

\begin{tabular}{|c|c|c|}
\hline Year & Author & Main finding \\
\hline 1999 & Soler & Increased NEU, TNF-a in colonized pts \\
\hline 2000 & Bresser & Increased TNF-a, MPO, IL-8 in H. Influenzae colonized pts \\
\hline 2000 & Hill & $\begin{array}{l}\text { Positive relation between MPO, NE, IL8, LTB4 and bacterial load in stable state. Increased MPO and decreased SLPI in Ps. } \\
\text { Aeroginosa colonized pts }\end{array}$ \\
\hline 2000 & Sethi & Increased TNFa, NE in $\mathrm{H}$. Influenae and M. Catarrhalis exacerbations \\
\hline 2000 & Crooks & Decrease in MPO, IL8, LTB4, after treatment of bacterial exacerbations \\
\hline 2001 & Gombertz & Decrease in LTB4 after treatment of purulent exacerbations \\
\hline 2002 & Patel & Positive relation between IL8 and bacterial load. Decreased SLPI in colonized pts \\
\hline 2003 & White & Decrease in LTB4, increase in SLPI after bacteria eradication on exacerbations \\
\hline
\end{tabular}

ing may be of particular clinical importance as airway eosinophilia could be used as an indicator of viral infection during an exacerbation. The important role of eosinophils in the pathogenesis of COPD exacerbations is further supported by studies in bronchial biopsies and sputum samples, which show increased eosinophil numbers and eosinophil mediators in COPD patients during exacerbations [41-46]. Eosinophils may be actively involved in the pathogenesis of viral-induced COPD exacerbations through the release of destructive enzymes, reactive oxygen species and inflammatory mediators.

\section{Ic Atypical bacteria}

Atypical pathogens with potential importance in acute exacerbations include M. Pneumoniae, C. Pneumoniae and Legionella spp. Considerable confusion exists in the literature regarding the significance of these potential pathogens in acute exacerbations of COPD[47]. This is partly due to differences in the techniques used to detect the presence of atypical infections. When a fourfold increase in antibody titter or a positive culture or RT-PCR is used, M. Pneumoniae and Legionella are rare and C. Pneumoniae infection may be involved in up to $9 \%$ of COPD exacerbations[30,48-50]. Moreover, chronic colonization with C. Pneumoniae may be associated with a higher rate of COPD exacerbations[51]. C. Pneumonia infection can amplify inflammation in the airways of COPD patients by stimulating the production and expression of cytokines, chemokines and adhesion molecules[52]. However, clear evidence showing a direct relationship between increased inflammation and C. Pneumoniae infection during COPD exacerbations is yet lacking[50].

\section{Increased air pollution}

Epidemiologists have linked ambient particulate air pollution (PM) exposure with exacerbations of pre-existing pulmonary diseases, such as COPD[53]. PM-mediated enhancement of airway inflammation is a central pathogenetic mechanism by which PM exposure leads to exacerbation of inflammatory pulmonary diseases [54-56]. It has been suggested that PM exposure induces lung inflam- mation by an increase in Reactive Oxygen Species $[57,58]$. To the best of our knowledge there are no in vivo studies on the effect of PM exposure on airway inflammation in COPD patients. There is also lack of information on airway inflammation during PM exposure induced COPD exacerbations, which may be due to difficulties in defining such exacerbations.

\section{Intrinsic factors}

I. Increased oxidative stress

An imbalance between oxidants and antioxidants may be involved in the development of COPD exacerbations. Almost a decade ago Rahman et al showed that plasma Trolox equivalent antioxidant capacity is decreased in patients presenting with acute exacerbation of COPD[59]. Recent reports suggest that 8-isoprostane levels are increased in exhaled breath condensate of COPD patients during exacerbations, while levels of the antioxidant enzyme glutathione(GSH) in bronchoalveolar lavage fluid are decreased[60,61]. Oxidative stress may be closely associated to increased inflammation during exacerbations[60,62].

Oxidant stimuli induce cellular expression of inducible nitric oxide synthase and heme-oxygenase-1(HO-1) and increase nitrotyrosine formation. We have shown that there is increased HO-1 expression and nitrotyrosine formation in the airways of COPD patients during severe exacerbations relatively to stable state and that this is accompanied by an increase in indices of neutrophilic inflammation, i.e. neutrophil numbers, MPO and IL-8 levels[62]. Evidence for a close association between oxidative stress, airway neutrophilia and increased IL-8 during severe COPD exacerbations is also supported by Drost et al[60]. A certain limitation in the study by Drost et al is the fact that different patients were examined on exacerbation and on stable state.

Oxidative stress induces the transcription of various inflammatory factors, such as nuclear factor-kappaB (NF$\kappa \mathrm{B})$ and activator protein-1 (AP-1)[63]. It has been shown that NF- $\mathrm{kB}$ DNA binding in sputum inflammatory cells is 
increased during COPD exacerbations[64]. Other investigators have reported increased nuclear localisation of $\mathrm{p} 65$, which is a signal of NF- $\mathrm{kB}$ activation, in sputum macrophages during COPD exacerbations[65]. NF- $\kappa B$ is important for transcription of IL- 8 gene and oxidative stress may induce or amplify airway neutrophilia by inducing the transcription of IL-8 gene[66]. In support of this hypothesis both we and Drost et al have found increased IL-8 levels and neutrophil numbers associated with increased oxidative stress on severe COPD exacerbations[60,62].

Activated neutrophils and other inflammatory cells can in turn release reactive oxygen species and increase airway oxidative stress. Because oxidative stress can induce inflammation and vice versa, it is not clear which of the two, oxidative stress or inflammation, is primarily involved in the mechanisms of COPD exacerbations-[the chicken and egg problem].

\section{Altered immunity}

Alterations in innate and adaptive immunity are implicated in COPD pathogenesis[67]. Evidence favouring participation of the adaptive immune response in COPD includes the several reports of increased numbers of $\mathrm{T}$ lymphocytes, specifically CD8+ve T-cells with a "type 1 "profile [68-71]. It is still unknown whether these alterations are triggered by cigarette smoking, viral infections, or there is a genetic predisposal. We have recently shown that CD8+ve Tlymphocytes may mediate their destructive effects in COPD through increased perforin expression and cytotoxic activity[72]. It would be reasonable to assume that lymphocytes may be implicated in the mechanisms of increased inflammation during COPD exacerbations.

According to our observations changes in lymphocyte subpopulations occur during severe COPD exacerbations[73]. In specific, there is a further increase in CD8+ve $T$ cells and this is rather associated with increased CD8+ve type 2 cells compared to type 1 . This finding suggests that $\mathrm{Tc} 1$ and Tc2 responses may fluctuate in relation to the different phase (exacerbation versus stable state) of the disease in the same patient. Similar observations have been made in other inflammatory diseases[74]. A relative increase of Tc2 versus Tc1 cells may result in impaired immunity, increased susceptibility to viral infections and increased inflammation [75-77].

Although Saetta et al also found increased $\mathrm{T}$ cell numbers in endobronchial biopsies from chronic bronchitis patients on mild exacerbations, no difference was detected in CD4 or CD8+ve cell numbers[45]. This discrepancy may be attributed to the fact that we examined sputum samples (not biopsies) from COPD patients (not chronic bronchitis) on severe exacerbation (not mild exacerbation). Moreover, Saetta et al compared different patients on exacerbation and on stable state, which could be a limitation in their study. However, finding increased $\mathrm{T}$ cell numbers still adds evidence to the argument that immune responses may be involved in the mechanisms of increased airway inflammation during COPD exacerbations.

\section{Increased baseline levels of inflammation}

It would be logical to assume that small increases in airway inflammation in patients with already increased baseline levels of inflammation can easily trigger a COPD exacerbation. This presumes the existence of an inflammatory threshold, above which exacerbation occurs. In relation to this hypothesis, Bhowmik et al showed that COPD patients with frequent exacerbations ( $\geq 3$ episodes/ year) have increased baseline sputum IL- 6 and IL- 8 levels[78]. However, it was not examined whether this was related to bacterial colonization, as bacterial colonization can increase airway inflammation and exacerbation rates. The same group also showed faster rises over time in plasma fibrinogen and sputum IL-6 in patients with frequent exacerbations[79].

On the contrary, Gombertz et al did not detect any difference in neutrophilic mediators (including IL-8) between frequent ( $\geq 3$ episodes/year) and infrequent exacerbators[80]. Interestingly, when patients with bronchiectasis were excluded from the analysis, SLPI was found to be lower in COPD patients with frequent exacerbations, which suggests that COPD patients with bronchiectasis may represent a distinct group. Fujimoto et al also report no difference in baseline IL-8 and markers of eosinophilic inflammation between stable and unstable COPD patients[42]. However, results between this and other studies are not comparable due to lower exacerbation rates (mean 1 episode/year) in the unstable COPD group in this study.

In conclusion, data relating baseline airway inflammation to exacerbation frequency are rather controversial. Part of the existing confusion may be due to significant heterogeneity among COPD patients and to the existence of several factors, like bacterial colonization and bronchiectasis that may increase airway inflammation. In particular, COPD patients with bronchiectasis may represent a distinct group characterized by higher rates of bacterial colonization, increased baseline levels of airway inflammation and longer symptom recovery times at exacerbation[81].

\section{Inflammation and pathophysiology of exacerbations}

Episodes of COPD exacerbations are characterized by an acute increase in a patient's baseline dyspnoea, cough and/or sputum production[8]. Severe exacerbations are 
also associated with worsening of pulmonary gas exchange that may lead to hypoxemia with or without hypercapnia[82]. In order to support a role for airway inflammation in COPD exacerbations the mechanisms which are induced by airway inflammation need to be related to the symptoms and pathophysiology of exacerbations.

Increased airway inflammation induces many pathologic changes on the airways. Accumulation of inflammatory cells in the airway mucosa by itself causes airway wall thickening. Inflammatory cells can release potentially harmful mediators, such as proteases and reactive oxygen species[83]. Neutrophil and eosinophil products, like MPO, NE and eosinophilic cationic protein (ECP), have been found increased on exacerbations, and can cause inflammatory damage and increased permeability of the bronchial mucosa, resulting in airway oedema and protein exudation $[20,42,62,84]$. Inflammatory mediators, like ECP, can also induce bronchoconstriction by increasing achetinocholine release from parasynmpathetic nerves, while others, like NE, increase mucus secretion $[85,86]$. Furthermore, mediators of inflammation enhance coughing[87]. Potentially harmful mediators may be released not only by inflammatory cells but also by resident cells. For example, endothelin (ET)-1, which has been found increased on exacerbations, can be released by epithelial cells and stimulates mucus secretion and bronchial hyperesponsiveness[50]. The cascade of the above events leads to significant airway narrowing and increased airway secretions, while the patient suffers from increased cough, sputum, and/or increased dyspnea. The mechanisms of dyspnea are not entirely understood yet, but may be also associated with excessive airway narrowing and dynamic hyperinflation due to increased inflammation [88-90].

A brief summary of the pathophysiologic events that may link airway inflammation to the symptoms of COPD exacerbations and to respiratory failure is given in figure 1. Airway narrowing, caused by increased inflammation, leads to expiratory flow limitation and dynamic hyperinflation. Dynamic hyperinflation in turn increases work of respiratory muscles and oxygen consumption, resulting in decreased mixed venous oxygen tension[91]. Airway narrowing also increases ventilation/perfusion inequality, because a greater proportion of blood flow is diverted through lung units with low $\mathrm{V}^{\prime} / \mathrm{Q}^{\prime}$ ratios[91]. The combi-

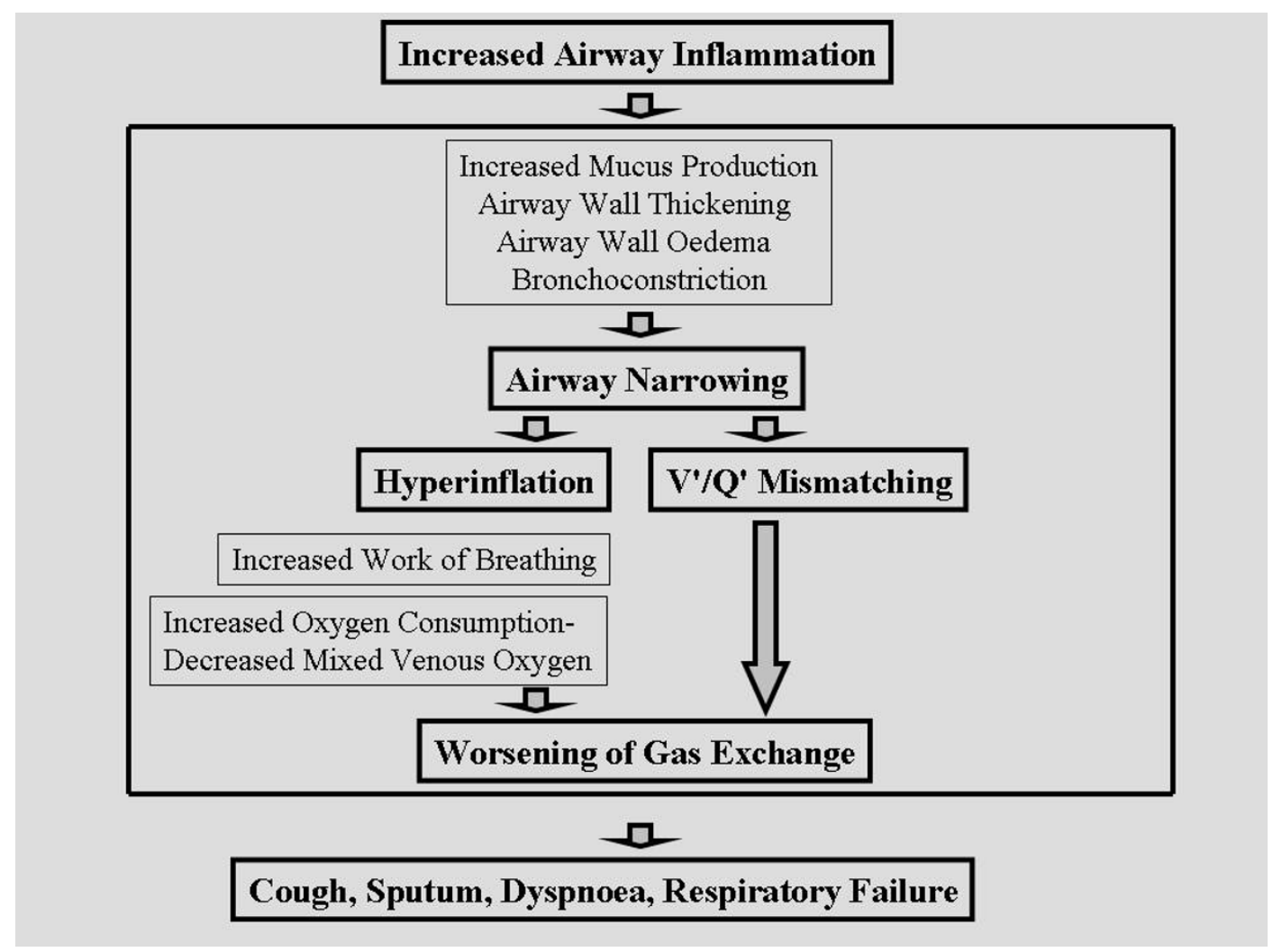

Figure I

Schematic presentation of the main pathophysiologic events of COPD exacerbations, starting from increased airway inflammation. 
nation of increased ventilation/perfusion inequality and decreased mixed venous oxygen tension significantly worsen gas exchange in patients with severe COPD exacerbations.

Increased airway inflammation would be also expected to increase lung tissue oxygen demand and oxygen consumption. In patients with acute lung injury no relation has been found between pulmonary oxygen consumption and lung inflammation, but there is no relevant data in COPD exacerbations[92].

\section{Anti-inflammatory therapy for exacerbations}

Despite the increasing recognition of the importance of airway inflammation in the development of COPD exacerbations, there is still confusion regarding the role of anti-inflammatory strategies in the prevention and treatment of COPD exacerbations[93,94]. There are studies showing a beneficial effect of inhaled steroids in preventing COPD exacerbations and systemic steroids in treating acute exacerbations, however the overall benefits for COPD patients in these studies are generally modest [9597]. Considering that inflammation in stable COPD is steroid resistant, this should not come as a great surprise[98]. Although the majority of COPD patients respond modestly to steroid therapy, there might be subgroup of patients, those with eosinophilic pattern of inflammation during exacerbations that may benefit the most from steroid administration. There is already evidence that stable patients with high sputum eosinophil counts are steroid responsive, but there is no relevant data on COPD exacerbations $[99,100]$. Identifying patients that may benefit from systemic steroid administration during exacerbations is of great importance, due to the serious adverse events frequently observed with this kind of treatment[97].

Other drugs with anti-inflammatory properties, like methylxanthines and mucolytic agents seem not to be effective on COPD exacerbations[8]. B-agonists are mainly administered as bronchodilators, although they may also have an anti-inflammatory role[101]. Novel drugs aimed at inhibiting targets, including NO synthase, phosphodiesterase 4 , proteases and various inflammatory mediators have not been tested during exacerbations yet.

\section{Conclusion}

It has been long postulated that airway inflammation may be increased during COPD exacerbations and this may be involved in the pathophysiology of exacerbations. There is now sufficient data to support such a hypothesis. Firstly, there are accumulating observations for increased inflammation during COPD exacerbations. Secondly, specific aetiological factors for this increase have been identified. Thirdly, possible mechanisms that may link airway inflammation with the pathophysiology of exacerbations have been unmasked. Despite significant advances in our understanding of the role of inflammation in COPD exacerbations, the existing anti-inflammatory treatments remain modest and there is little overall benefit for the patient. Further research is needed to target therapies to the appropriate patient populations and to develop new therapeutic strategies.

\section{Competing interests}

The author(s) declare that they have no competing interests.

\section{References}

I. Fletcher $\mathrm{C}$, Peto $\mathrm{R}$ : The natural history of chronic airflow obstruction. Br Med J 1977, I (6077): | 645-I648.

2. Miravitlles M, Ferrer M, Pont A, Zalacain R, Alvarez-Sala JL, Masa F, Verea $H$, Murio C, Ros F, Vidal R: Effect of exacerbations on quality of life in patients with chronic obstructive pulmonary disease: a 2 year follow up study. Thorax 2004, 59(5):387-395.

3. Seemungal TA, Donaldson GC, Paul EA, Bestall JC, Jeffries DJ, Wedzicha JA: Effect of exacerbation on quality of life in patients with chronic obstructive pulmonary disease. Am J Respir Crit Care Med I 998, I57(5 Pt I):|4|8-|422.

4. Burrows B, Earle RH: Course and prognosis of chronic obstructive lung disease. A prospective study of 200 patients. $N$ Engl J Med 1969, 280(8):397-404.

5. Donaldson GC, Seemungal TA, Bhowmik A, Wedzicha JA: Relationship between exacerbation frequency and lung function decline in chronic obstructive pulmonary disease. Thorax 2002, 57( I 0):847-852.

6. Kanner RE, Anthonisen NR, Connett JE: Lower respiratory illnesses promote FEV(I) decline in current smokers but not ex-smokers with mild chronic obstructive pulmonary disease: results from the lung health study. Am J Respir Crit Care Med 200I, I 64(3):358-364.

7. Vestbo J, Prescott E, Lange P: Association of chronic mucus hypersecretion with FEVI decline and chronic obstructive pulmonary disease morbidity. Copenhagen City Heart Study Group. Am J Respir Crit Care Med 1996, I 53(5): I 530-I535.

8. Celli BR, MacNee W: Standards for the diagnosis and treatment of patients with COPD: a summary of the ATS/ERS position paper. Eur Respir J 2004, 23(6):932-946.

9. White AJ, Gompertz S, Stockley RA: Chronic obstructive pulmonary disease . 6: The aetiology of exacerbations of chronic obstructive pulmonary disease. Thorax 2003, 58(I):73-80.

10. Wedzicha JA: Exacerbations: etiology and pathophysiologic mechanisms. Chest 2002, I 2 I (5 Suppl): I36S- | 4IS.

II. Murphy TF, Sethi S, Niederman MS: The role of bacteria in exacerbations of COPD. A constructive view. Chest 2000, I I 8( I):204-209.

12. Miravitlles M: Exacerbations of chronic obstructive pulmonary disease: when are bacteria important? Eur Respir J Suppl 2002, 36:9s-19s.

13. Sethi S: Bacterial infection and the pathogenesis of COPD. Chest 2000, I I 7(5 SuppI I):286S-9IS.

14. Sethi S, Evans N, Grant BJ, Murphy TF: New strains of bacteria and exacerbations of chronic obstructive pulmonary disease. N Engl J Med 2002, 347(7):465-47I.

15. Sethi S, Wrona C, Grant BJ, Murphy TF: Strain-specific immune response to Haemophilus influenzae in chronic obstructive pulmonary disease. Am J Respir Crit Care Med 2004, I 69(4):448-453.

16. Chin CL, Manzel LJ, Lehman EE, Humlicek AL, Shi L, Starner TD, Denning GM, Murphy TF, Sethi S, Look DC: Haemophilus influenzae from patients with chronic obstructive pulmonary disease exacerbation induce more inflammation than colonizers. Am J Respir Crit Care Med 2005, I 72(I):85-9I.

17. Kawai T, Akira S: Pathogen recognition with Toll-like receptors. Curr Opin Immunol 2005, I 7(4):338-344. 
18. Soler N, Ewig S, Torres A, Filella X, Gonzalez J, Zaubet A: Airway inflammation and bronchial microbial patterns in patients with stable chronic obstructive pulmonary disease. Eur Respir J 1999, I 4(5): 1015-1022.

19. Bresser P, Out TA, van Alphen L, Jansen HM, Lutter R: Airway inflammation in nonobstructive and obstructive chronic bronchitis with chronic haemophilus influenzae airway infection. Comparison with noninfected patients with chronic obstructive pulmonary disease. Am J Respir Crit Care Med 2000, I 62(3 Pt I):947-952.

20. Hill AT, Campbell EJ, Hill SL, Bayley DL, Stockley RA: Association between airway bacterial load and markers of airway inflammation in patients with stable chronic bronchitis. Am J Med 2000, I 09(4):288-295.

21. Patel IS, Seemungal TA, Wilks M, Lloyd-Owen SJ, Donaldson GC, Wedzicha JA: Relationship between bacterial colonisation and the frequency, character, and severity of COPD exacerbations. Thorax 2002, 57(9):759-764.

22. Hurst JR, Wilkinson TM, Perera WR, Donaldson GC, Wedzicha JA: Relationships among bacteria, upper airway, lower airway, and systemic inflammation in COPD. Chest 2005, I 27(4): I $219-1226$.

23. Sethi S, Muscarella K, Evans N, Klingman KL, Grant BJ, Murphy TF: Airway inflammation and etiology of acute exacerbations of chronic bronchitis. Chest 2000, I |8(6): | 557-I565.

24. White AJ, Gompertz S, Bayley DL, Hill SL, O'Brien C, Unsal I, Stockley $R A$ : Resolution of bronchial inflammation is related to bacterial eradication following treatment of exacerbations of chronic bronchitis. Thorax 2003, 58(8):680-685.

25. Hurst JR, Perera WR, Wilkinson TM, Donaldson GC, Wedzicha JA: Systemic, Upper and Lower Airway Inflammation at Exacerbation of COPD. Am J Respir Crit Care Med 2005.

26. Crooks SW, Bayley DL, Hill SL, Stockley RA: Bronchial inflammation in acute bacterial exacerbations of chronic bronchitis: the role of leukotriene B4. Eur Respir J 2000, I 5(2):274-280.

27. Gompertz S, O'Brien C, Bayley DL, Hill SL, Stockley RA: Changes in bronchial inflammation during acute exacerbations of chronic bronchitis. Eur Respir J 200 I, I 7(6): I II2-I I I9.

28. Gump DW, Phillips CA, Forsyth BR, Mclntosh K, Lamborn KR, Stouch WH: Role of infection in chronic bronchitis. Am Rev Respir Dis 1976, I I3(4):465-474.

29. Buscho RO, Saxtan D, Shultz PS, Finch E, Mufson MA: Infections with viruses and Mycoplasma pneumoniae during exacerbations of chronic bronchitis. J Infect Dis 1978, I37(4):377-383.

30. Smith CB, Golden CA, Kanner RE, Renzetti ADJ: Association of viral and Mycoplasma pneumoniae infections with acute respiratory illness in patients with chronic obstructive pulmonary diseases. Am Rev Respir Dis 1980, I 2 I(2):225-232.

31. Seemungal T, Harper-Owen R, Bhowmik A, Moric I, Sanderson G, Message S, Maccallum P, Meade TW, Jeffries DJ, Johnston SL, Wedzicha JA: Respiratory viruses, symptoms, and inflammatory markers in acute exacerbations and stable chronic obstructive pulmonary disease. Am J Respir Crit Care Med 200I, I 64(9): 1618-1623.

32. Rohde G, Wiethege A, Borg I, Kauth M, Bauer TT, Gillissen A, Bufe A, Schultze-Werninghaus G: Respiratory viruses in exacerbations of chronic obstructive pulmonary disease requiring hospitalisation: a case-control study. Thorax 2003, 58(I):37-42.

33. Message SD, Johnston SL: Host defense function of the airway epithelium in health and disease: clinical background. J Leukoc Biol 2004, 75(I):5-17.

34. Peebles RSJ, Graham BS: Viruses, dendritic cells and the lung. Respir Res 200I, 2(4):245-249.

35. Gern JE, Busse WW: The role of viral infections in the natural history of asthma. J Allergy Clin Immunol 2000, I 06(2):20 I-2 I 2

36. Meshi B, Vitalis TZ, lonescu D, Elliott WM, Liu C, Wang XD, Hayashi $S$, Hogg JC: Emphysematous lung destruction by cigarette smoke. The effects of latent adenoviral infection on the lung inflammatory response. Am J Respir Cell Mol Biol 2002, 26(I):52-57

37. Retamales I, Elliott WM, Meshi B, Coxson HO, Pare PD, Sciurba FC, Rogers RM, Hayashi S, Hogg JC: Amplification of inflammation in emphysema and its association with latent adenoviral infection. Am J Respir Crit Care Med 200I, I 64(3):469-473.

38. Seemungal TA, Harper-Owen R, Bhowmik A, Jeffries DJ, Wedzicha JA: Detection of rhinovirus in induced sputum at exacerba- tion of chronic obstructive pulmonary disease. Eur Respir 2000, I 6(4):677-683.

39. Papi A, Bellettato CM, Braccioni F, Romagnoli M, Casolari P, Caramori G, Fabbri LM, Johnston SL, Fujimoto K, Yasuo M, Urushibata K, Hanaoka M, Koizumi T, Kubo K, Rohde G, Gevaert P, Holtappels G, Fransen L, Borg I, Wiethege A, Arinir U, Tavernier J, Schultze-Werninghaus $G$, Bachert $C$, Bocchino V, Bertorelli G, Bertrand CP, Ponath PD, Newman W, Franco C, Marruchella A, Merlini S, Del Donno M, Zhuo $X$, Olivieri D: Infections and Airway Inflammation in Chronic Obstructive Pulmonary Disease Severe Exacerbations Airway inflammation during stable and acutely exacerbated chronic obstructive pulmonary disease Soluble interleukin-5 receptor alpha is increased in acute exacerbation of chronic obstructive pulmonary disease Eotaxin and CCR3 are up-regulated in exacerbations of chronic bronchitis. Am J Respir Crit Care Med 2006, 25(4):640-646.

40. Rohde G, Gevaert P, Holtappels G, Fransen L, Borg I, Wiethege A, Arinir U, Tavernier J, Schultze-Werninghaus G, Bachert C: Soluble interleukin-5 receptor alpha is increased in acute exacerbation of chronic obstructive pulmonary disease. Int Arch Allergy Immunol 2004, I 35( I):54-6I.

4I. Bocchino V, Bertorelli G, Bertrand CP, Ponath PD, Newman W, Franco C, Marruchella A, Merlini S, Del Donno M, Zhuo X, Olivieri $D$ : Eotaxin and CCR3 are up-regulated in exacerbations of chronic bronchitis. Allergy 2002, 57(I): 17-22.

42. Fujimoto K, Yasuo M, Urushibata K, Hanaoka M, Koizumi T, Kubo K: Airway inflammation during stable and acutely exacerbated chronic obstructive pulmonary disease. Eur Respir J 2005, 25(4):640-646.

43. Hargreave FE, Dolovich J, Pizzichini E, Pizzichini M: Airway eosinophilia in chronic bronchitis during exacerbations. $\mathrm{Am}$ Respir Crit Care Med 1996, I 53(5): I726-I727.

44. Saetta M, Di Stefano A, Maestrelli P, Turato G, Mapp CE, Pieno M, Zanguochi G, Del Prete G, Fabbri LM: Airway eosinophilia and expression of interleukin-5 protein in asthma and in exacerbations of chronic bronchitis. Clin Exp Allergy 1996, 26(7):766-774.

45. Saetta M, Di Stefano A, Maestrelli P, Turato G, Ruggieri MP, Roggeri A, Calcagni P, Mapp CE, Ciaccia A, Fabbri LM: Airway eosinophilia in chronic bronchitis during exacerbations. Am J Respir Crit Care Med 1994, I50(6 Pt I): I646-I652.

46. Zhu J, Qiu YS, Majumdar S, Gamble E, Matin D, Turato G, Fabbri LM, Barnes N, Saetta M, Jeffery PK: Exacerbations of Bronchitis: bronchial eosinophilia and gene expression for interleukin-4, interleukin-5, and eosinophil chemoattractants. Am J Respir Crit Care Med 2001, I 64(1):109-1 16

47. Sethi S: New developments in the pathogenesis of acute exacerbations of chronic obstructive pulmonary disease. Curr Opin Infect Dis 2004, I 7(2): I I3-I I9.

48. Blasi F, Legnani D, Lombardo VM, Negretto GG, Magliano E, Pozzoli R, Chiodo F, Fasoli A, Allegra L: Chlamydia pneumoniae infection in acute exacerbations of COPD. Eur Respir J 1993, 6(I): 19-22

49. Beaty CD, Grayston JT, Wang SP, Kuo CC, Reto CS, Martin TR: Chlamydia pneumoniae, strain TWAR, infection in patients with chronic obstructive pulmonary disease. Am Rev Respir Dis I991, I44(6): | 408-1410.

50. Roland M, Bhowmik A, Sapsford RJ, Seemungal TA, Jeffries DJ, Warner TD, Wedzicha JA: Sputum and plasma endothelin-I levels in exacerbations of chronic obstructive pulmonary disease. Thorax 200I, 56(I):30-35.

5I. Blasi F, Damato S, Cosentini R, Tarsia P, Raccanelli R, Centanni S, Allegra L: Chlamydia pneumoniae and chronic bronchitis: association with severity and bacterial clearance following treatment. Thorax 2002, 57(8):672-676.

52. Clementsen P, Permin H, Norn S: Chlamydia pneumoniae infection and its role in asthma and chronic obstructive pulmonary disease. J Investig Allergol Clin Immunol 2002, I 2(2):73-79.

53. Sunyer J, Saez M, Murillo C, Castellsague J, Martinez F, Anto JM: Air pollution and emergency room admissions for chronic obstructive pulmonary disease: a 5-year study. Am J Epidemiol 1993, I37(7):701-705.

54. Ohtoshi T, Takizawa H, Okazaki H, Kawasaki S, Takeuchi N, Ohta K Ito K: Diesel exhaust particles stimulate human airway epithelial cells to produce cytokines relevant to airway inflammation in vitro. J Allergy Clin Immunol I998, I0 I (6 Pt I):778-785. 
55. Rudell B, Blomberg A, Helleday R, Ledin MC, Lundback B, Stjernberg $N$, Horstedt $P$, Sandstrom T: Bronchoalveolar inflammation after exposure to diesel exhaust: comparison between unfiltered and particle trap filtered exhaust. Occup Environ Med 1999, 56(8):527-534.

56. Seaton A, MacNee W, Donaldson K, Godden D: Particulate air pollution and acute health effects. Lancet 1995, 345(8943): $176-178$.

57. Tao F, Gonzalez-Flecha B, Kobzik L: Reactive oxygen species in pulmonary inflammation by ambient particulates. Free Radic Biol Med 2003, 35(4):327-340.

58. MacNee W, Donaldson K: Exacerbations of COPD: environmental mechanisms. Chest 2000, I I 7(5 Suppl 2):390S-7S.

59. Rahman I, Morrison D, Donaldson K, MacNee W: Systemic oxidative stress in asthma, COPD, and smokers. Am J Respir Crit Care Med 1996, I 54(4 Pt I): I055-1060.

60. Drost EM, Skwarski KM, Sauleda J, Soler N, Roca J, Agusti A, MacNee $W$ : Oxidative stress and airway inflammation in severe exacerbations of COPD. Thorax 2005, 60(4):293-300.

61. Biernacki WA, Kharitonov SA, Barnes PJ: Increased leukotriene B4 and 8-isoprostane in exhaled breath condensate of patients with exacerbations of COPD. Thorax 2003, 58(4):294-298.

62. Tsoumakidou M, Tzanakis N, Chrysofakis G, Siafakas NM: Nitrosative stress, heme oxygenase-I expression and airway inflammation during severe exacerbations of COPD. Chest 2005, I27(6): $1911-1918$.

63. Rahman I, MacNee W: Role of transcription factors in inflammatory lung diseases. Thorax 1998, 53(7):60 I-6I 2

64. Drost EM, Ritchie HE, Skwarska E, al : NF-kB activation in airway leucocytes in COPD patients. Eur Respir J 200I, I 6:260s.

65. Caramori G, Romagnoli M, Casolari P, Bellettato C, Casoni G, Boschetto P, Chung KF, Barnes PJ, Adcock IM, Ciaccia A, Fabbri LM, Papi $A:$ Nuclear localisation of p65 in sputum macrophages but not in sputum neutrophils during COPD exacerbations. Thorax 2003, 58(4):348-35I.

66. Roebuck KA: Oxidant stress regulation of IL-8 and ICAM-I gene expression: differential activation and binding of the transcription factors AP-I and NF-kappaB (Review). Int J Mol Med 1999, 4(3):223-230.

67. Hogg JC: Pathophysiology of airflow limitation in chronic obstructive pulmonary disease. Lancet 2004, 364(9435):709-721

68. Tsoumakidou M, Tzanakis N, Kyriakou D, Chrysofakis G, Siafakas NM: Inflammatory cell profiles and T-lymphocyte subsets in chronic obstructive pulmonary disease and severe persistent asthma. Clin Exp Allergy 2004, 34(2):234-240.

69. Saetta M, Mariani M, Panina-Bordignon P, Turato G, Buonsanti C, Baraldo S, Bellettato CM, Papi A, Corbetta L, Zuin R, Sinigaglia F, Fabbri LM: Increased expression of the chemokine receptor $C X C^{3} 3$ and its ligand CXCLI 0 in peripheral airways of smokers with chronic obstructive pulmonary disease. Am J Respir Crit Care Med 2002, I 65(I 0): | 404-| 409.

70. O'Shaughnessy TC, Ansari TW, Barnes NC, Jeffery PK: Inflammation in bronchial biopsies of subjects with chronic bronchitis: inverse relationship of CD8+ T lymphocytes with FEVI. Am J Respir Crit Care Med I 997, I 55(3):852-857.

7I. Grumelli S, Corry DB, Song LZ, Song L, Green L, Huh J, Hacken J, Espada R, Bag R, Lewis DE, Kheradmand F: An immune basis for lung parenchymal destruction in chronic obstructive pulmonary disease and emphysema. PLoS Med 2004, I (I):e8.

72. Chrysofakis G, Tzanakis N, Kyriakoy D, Tsoumakidou M, Tsiligianni I, Klimathianaki M, Siafakas NM: Perforin expression and cytotoxic activity of sputum CD8+ lymphocytes in patients with COPD. Chest 2004, I 25(I):71-76.

73. Tsoumakidou M, Tzanakis N, Chrysofakis G, Kyriakou D, Siafakas NM: Changes in sputum T-lymphocyte subpopulations at the onset of severe exacerbations of chronic obstructive pulmonary disease. Respir Med 2005, 99(5):572-579.

74. Prezzi C, Casciaro MA, Francavilla V, Schiaffella E, Finocchi L, Chircu LV, Bruno G, Sette A, Abrignani S, Barnaba V: Virus-specific CD8(+) $\mathrm{T}$ cells with type I or type 2 cytokine profile are related to different disease activity in chronic hepatitis $\mathbf{C}$ virus infection. Eur J Immunol 200I, 3 I (3):894-906.

75. Wirth $S$, van den Broek M, Frossard CP, Hugin AW, Leblond I, Pircher H, Hauser C: CD8(+) T cells secreting type 2 lym- phokines are defective in protection against viral infection. Cell Immunol 2000, 202(I): I3-22.

76. Kemeny DM, Noble A, Holmes BJ, Diaz-Sanchez D: Immune regulation: a new role for the CD8+ T cell. Immunol Today 1994, I5(3): I07-I I0.

77. Seder RA, Le Gros GG: The functional role of CD8+ T helper type 2 cells. J Exp Med I995, I 8 I (I):5-7.

78. Bhowmik A, Seemungal TA, Sapsford RJ, Wedzicha JA: Relation of sputum inflammatory markers to symptoms and lung function changes in COPD exacerbations. Thorax 2000 55(2): I | 4- I 20.

79. Donaldson GC, Seemungal TA, Patel IS, Bhowmik A, Wilkinson TM, Hurst JR, Maccallum PK, Wedzicha JA: Airway and systemic inflammation and decline in lung function in patients with COPD. Chest 2005, I 28(4): 1995-2004.

80. Gompertz S, Bayley DL, Hill SL, Stockley RA: Relationship between airway inflammation and the frequency of exacerbations in patients with smoking related COPD. Thorax 200 I, 56(I):36-4I.

8I. Patel IS, Vlahos I, Wilkinson TM, Lloyd-Owen SJ, Donaldson GC, Wilks M, Reznek RH, Wedzicha JA: Bronchiectasis, exacerbation indices, and inflammation in chronic obstructive pulmonary disease. Am / Respir Crit Care Med 2004, I 70(4):400-407.

82. Calverley PM: Respiratory failure in chronic obstructive pulmonary disease. Eur Respir J Suppl 2003, 47:26s-30s.

83. Barnes PJ: Mediators of chronic obstructive pulmonary disease. Pharmacol Rev 2004, 56(4):5I5-548.

84. Gompertz S, Stockley RA: Inflammation--role of the neutrophil and the eosinophil. Semin Respir Infect 2000, I5(I):|4-23.

85. Jeffery $\mathrm{P}$, Zhu J: Mucin-producing elements and inflammatory cells. Novartis Found Symp 2002, 248:5I-68; discussion 68-75, 277 82.

86. Fryer AD, Adamko DJ, Yost BL, Jacoby DB: Effects of inflammatory cells on neuronal $\mathrm{M} 2$ muscarinic receptor function in the lung. Life Sci 1999, 64(6-7):449-455.

87. Bolser DC: Experimental models and mechanisms of enhanced coughing. Pulm Pharmacol Ther 2004, I 7(6):383-388.

88. Parker CM, Voduc N, Aaron SD, Webb KA, O'Donnell DE: Physiological changes during symptom recovery from moderate exacerbations of COPD. Eur Respir J 2005, 26(3):420-428.

89. Stevenson NJ, Walker PP, Costello RW, Calverley PM: Lung Mechanics and Dyspnea during Exacerbations of Chronic Obstructive Pulmonary Disease. Am J Respir Crit Care Med 2005.

90. Dyspnea. Mechanisms, assessment, and management: a consensus statement. American Thoracic Society. Am J Respir Crit Care Med I999, I59(I):32I-340.

91. Barbera JA, Roca J, Ferrer A, Felez MA, Diaz O, Roger N, RodriguezRoisin R: Mechanisms of worsening gas exchange during acute exacerbations of chronic obstructive pulmonary disease. Eur Respir J 1997, I0(6): |285-1291.

92. Jolliet P, Thorens JB, Nicod L, Pichard C, Kyle U, Chevrolet JC: Relationship between pulmonary oxygen consumption, lung inflammation, and calculated venous admixture in patients with acute lung injury. Intensive Care Med 1996, 22(4):277-285.

93. Calverley PM: The role of corticosteroids in chronic obstructive pulmonary disease. Semin Respir Crit Care Med 2005, 26(2):235-245.

94. Wedzicha JA: Oral corticosteroids for exacerbations of chronic obstructive pulmonary disease. Thorax 2000, 55 Suppl I:S23-7.

95. Davies L, Angus RM, Calverley PM: Oral corticosteroids in patients admitted to hospital with exacerbations of chronic obstructive pulmonary disease: a prospective randomised controlled trial. Lancet 1999, 354(9 | 77):456-460.

96. Niewoehner DE, Erbland ML, Deupree RH, Collins D, Gross NJ, Light RW, Anderson P, Morgan NA: Effect of systemic glucocorticoids on exacerbations of chronic obstructive pulmonary disease. Department of Veterans Affairs Cooperative Study Group. N Engl J Med 1999, 340(25): 194I-1947.

97. Wood-Baker RR, Gibson PG, Hannay M, Walters EH, Walters JA: Systemic corticosteroids for acute exacerbations of chronic obstructive pulmonary disease. Cochrane Database Syst Rev 2005:CD00I288.

98. Barnes PJ: Corticosteroid resistance in airway disease. Proc Am Thorac Soc 2004, I(3):264-268. 
99. Brightling CE, Monteiro W, Ward R, Parker D, Morgan MD, Wardlaw AJ, Pavord ID: Sputum eosinophilia and short-term response to prednisolone in chronic obstructive pulmonary disease: a randomised controlled trial. Lancet 2000, 356(9240): | 480-|485.

100. Brightling CE, McKenna S, Hargadon B, Birring S, Green R, Siva R, Berry M, Parker D, Monteiro W, Pavord ID, Bradding P: Sputum eosinophilia and the short term response to inhaled mometasone in chronic obstructive pulmonary disease. Tho$\operatorname{rax} 2005,60(3): 193-198$.

101. Barnes PJ: Effect of beta-agonists on inflammatory cells. J Allergy Clin Immunol 1999, I04(2 Pt 2):SI0-7.

Publish with Biomed Central and every scientist can read your work free of charge

"BioMed Central will be the most significant development for disseminating the results of biomedical research in our lifetime. "

Sir Paul Nurse, Cancer Research UK

Your research papers will be:

- available free of charge to the entire biomedical community

- peer reviewed and published immediately upon acceptance

- cited in PubMed and archived on PubMed Central

- yours - you keep the copyright

Submit your manuscript here:

http://www.biomedcentral.com/info/publishing_adv.asp
BioMedcentral 